\title{
Synthesis and Characterization of new Binuclear Chromium, Cadmium Complexes based on Terpyridine and Phenanthroline
}

\author{
ALIREZA OVEISIKEIKHA ${ }^{1}$ and HAMIDEH SARAVANI ${ }^{2 *}$ \\ ${ }_{1,2}$ Inorganic Chemistry Laboratory, Department of Chemistry, University of Sistan and Baluchestan, \\ P. O. Box 98135-674, Zahedan, Iran. \\ ${ }^{*}$ Corresponding author E-mail: saravani@chem.usb.ac.ir \\ http://dx.doi.org/10.13005/ojc/340317
}

(Received: April 27, 2018; Accepted: June 07, 2018)

\begin{abstract}
In this research, four binuclear complexes:[(phen $) \mathrm{Cd}\left(\mathrm{NO}_{3}\right)_{2}(\mu$-phen-dion $\left.) \mathrm{Cr}\left(\mathrm{NO}_{3}\right)_{2}(\mathrm{phen})\right]$ $\left(\mathrm{NO}_{3}\right)_{2}$, [Cr(4-Ptpy)( $\mu$-phen-dion)] $\left(\mathrm{NO}_{3}\right)\left[\mathrm{Cd}(4-\mathrm{Ptpy})\left(\mu\right.\right.$-phen-dion)] $\left(\mathrm{NO}_{3}\right)$, [Cr(4-Ptpy)( $\mu$-phen-dion)] $\left(\mathrm{NO}_{3}\right) \mathrm{Cr}(4-\mathrm{Ptpy})(\mu$-phen-dion) $)\left(\mathrm{NO}_{3}\right)$, and [Cd(4-Ptpy)( $\mu$-phen-dion)] $\left(\mathrm{NO}_{3}\right)$ [Cd(4-Ptpy)( $\mu$-phen-dion)] $\left(\mathrm{NO}_{3}\right)$ were synthesized using reaction of chromium(III) nitrate nonahydrate, cadmium (II) nitrate tetrahydrate, phendion, and 4-phenylterepyrydine. The complexes were characterized using FT-IR spectroscopy, UV-Vis spectroscopy, ${ }^{1} \mathrm{H}$ NMR, elemental analysis, and cyclic voltammetery (CV). These complexes were found to be binuclear coordination complexes. The chromium and cadmium centers were achieved hexacoordination by coordinating with 4-phenylterepyrydine groups, as tridentate chelating ligands and phendion as bidentate chelating ligands.
\end{abstract}

Keywords: Binuclear complex, Phendion, chromium, Cadmium, and terpyrydine.

\section{INTRODUCTION}

Oligopyridines and their metal complexes have gained extensive attention in the last decades ${ }^{1}$. The materials including the metal-coordinated 2,2':6',2"-terpyridines (tpy) with spacers at C(4') have opened up new opportunities for various applications in electronics, catalysis, energy, and medicine due to their electron transfer properties ${ }^{2}$. The role of metal ions in the structure and function of binuclear complexes is essential, yet often unknown at the mechanistic and molecular level ${ }^{3}$. The hypotheses about principles governing selectivity and specificity of oligopyridines for a given bridged metal are often based on theoretical assumption.

An attractive metal-binding ligand is tpy which has an exceptionally well understood coordination chemistry. Many substitutions at $\mathrm{C}\left(4^{\prime}\right)$ directly linked to the pyridine ring, such as hydroxyl, ${ }^{4}$ chloro, ${ }^{5}$ bromo, ${ }^{6}$ methylthiol, ${ }^{7}$ methylsulfonyl, ${ }^{8}$ dimethylamino, ${ }^{9}$ and phenyl have been prepared.

Recently, many efforts have been performed in the synthesis and characterization of the binuclear complexes ${ }^{10-13}$. The bridged dinuclear complexes,

This is an Open Access article licensed under a Creative Commons Attribution-Non Commercial-Share Alike 4.0 International License (https://creativecommons.org/licenses/by-nc-sa/4.0/), which permits unrestricted Non Commercial use, distribution and reproduction in any medium, provided the original work is properly cited. 
in which the two metal centers are coupled each other in a conjugated system, are shown to be promising materials for new molecular electronic or magnetic materials ${ }^{14-19}$. Therefore, it is very important to investigate the synthesis and properties of these binuclear complexes. Hence, we decided to synthesize new binuclear complexes that can use as semiconductors.

\section{EXPERIMENTAL}

\section{Materials and physical techniques}

All synthetic work was performed at $60^{\circ} \mathrm{C}$. The water was distilled and deionized. $\mathrm{Cr}\left(\mathrm{NO}_{3}\right) 3.9 \mathrm{H}_{2} \mathrm{O}$, $\mathrm{Cd}\left(\mathrm{NO}_{3}\right) 2.4 \mathrm{H}_{2} \mathrm{O}$, phendion, 4-phenylterpyridine were purchesed from Merck Chemical Co. FTIR spectra were recorded as $\mathrm{KBr}$ pellets on a FT-IR JASCO 460 spectrophotometer and the UV-Vis spectra were taken at room temperature on a JASCO 7850 spectrometer.Cyclic voltammetry was performed at $20^{\circ} \mathrm{C}$ in an DMF solution with $0.1 \mathrm{M} \mathrm{TBAH}$ as a supporting electrolyte at scan rate $100 \mathrm{mV} \mathrm{s}^{-1} .1 \mathrm{H}$ NMR spectra were recorded on a Bruker AM 300 $\mathrm{MHz}$ spectrophotometer.

\section{Synthesis of [(4-Ptpy) $\mathrm{Cr}\left(\mathrm{NO}_{3}\right)$ ( $\mu$-phen-dion)} $\left.\mathrm{Cr}\left(\mathrm{NO}_{3}\right)(4-\mathrm{Ptpy})\right]\left(\mathrm{NO}_{3}\right)_{4}$

To an aqueous solution containing chromium nitrate $(1 \mathrm{mmol})$, phendion in ethanol ( $1 \mathrm{mmol}$ ) was added slowly and then the mixture was stirred at $60^{\circ} \mathrm{C}$ about 48 hours. After that, additional chromium nitrate $(1 \mathrm{mmol})$ was then added to the solution and was stirred at the same temperature. Following After $24 \mathrm{~h}, 2 \mathrm{mmol}$ of 4-Ptpy was added dropwise to the aqueous solution with continuous stirring for 3 days. Finally, solution filtered off and left to evaporate in beaker in air at room temperature, and green color crystals were formed. FT-IR $(\mathrm{KBr}) \mathrm{v}$ $=3391 \mathrm{~m}, 2477 \mathrm{~m}, 1705 \mathrm{~m}, 1613 \mathrm{~s}, 1453 \mathrm{~m}, 1333$ s, $835 \mathrm{~s}, 665 \mathrm{~s}\left(\mathrm{~cm}^{-1}\right)$. CHN Anal., Found; C, 57.80; H, 3.15; N, 15.81. Calc.; 57.91; H, 3.27; N, 15.93 . ${ }^{1} \mathrm{H}$ NMR (DMSO- $\left.\mathrm{d}_{6}\right): \delta=9.06(4 \mathrm{H}, \mathrm{m}), 8.71(4 \mathrm{H}, \mathrm{d}$, $\mathrm{J}=17 \mathrm{~Hz}), 8.16(4 \mathrm{H}, \mathrm{d}, \mathrm{J}=19 \mathrm{~Hz}), 7.89(4 \mathrm{H}, \mathrm{m})$, 7.64-6.98 $(20 \mathrm{H}, \mathrm{m}), 2.87(1 \mathrm{H}, \mathrm{s}), 2.64(1 \mathrm{H}, \mathrm{s}) . \mathrm{UV}$ (DMF): $\lambda \max =570,309$, and $263 \mathrm{~nm}$.

\section{Synthesis of [(4-Ptpy) $\mathrm{Cd}\left(\mathrm{NO}_{3}\right)$ ( $\mu$-phen-dion) $\left.\mathrm{Cr}\left(\mathrm{NO}_{3}\right)(4-\mathrm{Ptpy})\right]\left(\mathrm{NO}_{3}\right)_{3}$}

To prepare the $\left[(4-\mathrm{Ptpy}) \mathrm{Cd}\left(\mathrm{NO}_{3}\right)\right.$ ( $\mu$-phendion) $\mathrm{Cr}\left(\mathrm{NO}_{3}\right)$ (4-Ptpy)] $\left(\mathrm{NO}_{3}\right)_{3}$, chromium nitrate
(1 mmol), was added slowly to phendion ( $1 \mathrm{mmol})$ in ethanol, and then the mixture was stirred at $60^{\circ} \mathrm{C}$ for $48 \mathrm{~h}$, and then a dark colour solution was obtained. After that, cadmium(II) nitrate tetrahydrate $(1 \mathrm{mmol})$ was added dropwise to the reaction mixture and it was stirred. After 24 h, 2 mmol of 4-Ptpy was added to solution, and it turned to red colour. Then it was stirred for 3 days, and the solution was filtered. After 5 days, red crystals of [(4-Ptpy) $\mathrm{Cd}\left(\mathrm{NO}_{3}\right)(\mu$-phendion) $\left.\mathrm{Cr}\left(\mathrm{NO}_{3}\right)(4-\mathrm{Ptpy})\right]\left(\mathrm{NO}_{3}\right)_{3}$ were formed. FT-IR $(\mathrm{KBr}) v=3420 \mathrm{~m}, 3080 \mathrm{~m}, 2924 \mathrm{~m}, 1606 \mathrm{~s}, 1383 \mathrm{~s}$,

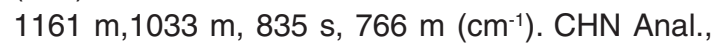
Found; C, 61.20; H, 3.15; N, 12.98. Calc.; 61.36; H, 3.40; N, 13.25. ${ }^{1} \mathrm{H}$ NMR (DMSO- $\left.\mathrm{d}_{6}\right): \delta=9.06(4 \mathrm{H}$, $\mathrm{m}), 8.71(4 \mathrm{H}, \mathrm{d}, \mathrm{J}=17 \mathrm{~Hz}), 8.16(4 \mathrm{H}, \mathrm{d}, \mathrm{J}=19 \mathrm{~Hz})$, $7.89(4 \mathrm{H}, \mathrm{m}), 7.64-6.98(2 \mathrm{HH}, \mathrm{m}), 2.87(1 \mathrm{H}, \mathrm{s}), 2.64$ $(1 \mathrm{H}, \mathrm{s})$. UV (DMF): $\lambda \max =570,309$, and $263 \mathrm{~nm}$.

\section{Synthesis of [(4-Ptpy)Cd( $\left.\mathrm{NO}_{3}\right)$ ( $\mu$-phen-dion) $\left.\mathrm{Cd}\left(\mathrm{NO}_{3}\right)(4-\mathrm{Ptpy})\right]\left(\mathrm{NO}_{3}\right)_{2}$}

To an aqueous solution containing cadmium(II) nitrate tetrahydrate $(1 \mathrm{mmol})$, phendion in ethanol $(1 \mathrm{mmol})$ was added slowly and then the mixture was stirred at $60^{\circ} \mathrm{C}$ about 48 hours. After that, additional cadmium(II) nitrate $(1 \mathrm{mmol})$ was then added to the solution and was stirred at the same temperature. Following After $24 \mathrm{~h}, 2 \mathrm{mmol}$ of 4-Ptpy was added dropwise to the aqueous solution with continuous stirring for 3 days. Finally, solution filtered off and left to evaporate in beaker in air at room temperature, and red color crystals were formed. FT-IR (KBr) v = $3420 \mathrm{~m}, 2923 \mathrm{~m}, 1617 \mathrm{~s}$,

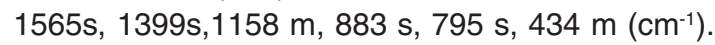
CHN Anal., Found; C, 57.87; H, 2.98; N, 12.35. Calc.; 58.04; $\mathrm{H}, 3.22 ; \mathrm{N}, 12.54$. $1 \mathrm{H}$ NMR (DMSO-d $\left.\mathrm{d}_{6}\right): \delta=$ $9.06(4 \mathrm{H}, \mathrm{m}), 8.71(4 \mathrm{H}, \mathrm{d}, \mathrm{J}=17 \mathrm{~Hz}), 8.16(4 \mathrm{H}, \mathrm{d}$, $\mathrm{J}=19 \mathrm{~Hz}), 7.89(4 \mathrm{H}, \mathrm{m}), 7.64-6.98(20 \mathrm{H}, \mathrm{m}), 2.87$ $(1 \mathrm{H}, \mathrm{s}), 2.64(1 \mathrm{H}, \mathrm{s})$. UV (DMF): $\lambda \max =570,309$, and $263 \mathrm{~nm}$.

\section{Synthesis of $\left[(\right.$ phen $) \mathrm{Cd}\left(\mathrm{NO}_{3}\right)_{2}(\mu$-phen-dion $)$ $\mathrm{Cr}\left(\mathrm{NO}_{3}\right) 2$ (phen)] $\left(\mathrm{NO}_{3}\right)_{2}$}

To prepare the $\left[(\right.$ phen $) \mathrm{Cd}\left(\mathrm{NO}_{3}\right)_{2}(\mu$-phendion) $\mathrm{Cr}\left(\mathrm{NO}_{3}\right)$ 2(phen)] $\left(\mathrm{NO}_{3}\right)_{2}, 1 \mathrm{mmol}$ chromium nitrate dissolved in water and $1 \mathrm{mmol}$ phendion in ethanol, then phendion added dropwise to the chromium nitrate, then the mixture was stirred at $60^{\circ} \mathrm{C}$ about 48 hours. After that, $1 \mathrm{mmol}$ cadmium(II) nitrate was added to the solution and was stirred at the same temperature, and $2 \mathrm{mmol}$ of 1,10 phenantroline 
was added slowly to the mixture, after $24 \mathrm{~h}$, mixture was filtered and a dark precipitate was formed. FT-IR (KBr) v = 3420 m, 3115 m, 2924 m, 1698 s, 1576s, 1441s, 839 s, 763 s, 557s (cm-1). CHN Anal., Found; C, 56.70; H, 2.81; N, 11.21. Calc.; 56.93; H, 3.05; N, 11.95. ${ }^{1} \mathrm{H}$ NMR (DMSO- $\left.\mathrm{d}_{6}\right): \delta=9.06(4 \mathrm{H}, \mathrm{m}), 8.71$ $(4 \mathrm{H}, \mathrm{d}, \mathrm{J}=17 \mathrm{~Hz}), 8.16(4 \mathrm{H}, \mathrm{d}, \mathrm{J}=19 \mathrm{~Hz}), 7.89$ $(4 \mathrm{H}, \mathrm{m}), 7.64-6.98(20 \mathrm{H}, \mathrm{m}), 2.87(1 \mathrm{H}, \mathrm{s}), 2.64$ $(1 \mathrm{H}, \mathrm{s})$. UV (DMF): $\lambda \max =572,305$, and $252 \mathrm{~nm}$.

\section{RESULTS AND DISCUSSION}

The reaction of 4-Ptpy and phendion as ligand with chromium(III) nitrate nonahydrate, and cadmium(II) nitrate tetrahydrate result in the formation of four binuclear complexes. The FT-IR spectra of the [(4-Ptpy) $\mathrm{Cr}\left(\mathrm{NO}_{3}\right)$ ( $\mu$-phen-dion) $\mathrm{Cr}\left(\mathrm{NO}_{3}\right)$ (4-Ptpy)] $\left(\mathrm{NO}_{3}\right)_{4}$ shows absorption bonds at $1300^{-1} 400 \mathrm{~cm}^{-1}$ that it is related to the coordination of carbonyl groups of the phendione ligand to the metal. The peaks at 419 and $451 \mathrm{~cm}^{-1}$ are assigned to the vibration of $\mathrm{Cr}-\mathrm{N}$ and $\mathrm{Cr}-\mathrm{O}$ bonds ${ }^{20-21}$. The characteristic band of [(phen) $\mathrm{Cd}\left(\mathrm{NO}_{3}\right) 2$ ( $\mu$-phen-dion) $\mathrm{Cr}\left(\mathrm{NO}_{3}\right) 2$ (phen)] $\left(\mathrm{NO}_{3}\right)_{2}$ is the peak at $1400-1650 \mathrm{~cm}^{-1}$ that is attributed to the phenanthroline ligand. The peaks at about 434 and $590 \mathrm{~cm}^{-1}$ are related to the $\mathrm{Cd}-\mathrm{N}$ and $\mathrm{Cd}-\mathrm{O}$ bonds, confirming the formation of the binuclear complex. The peaks of $\mathrm{C}=\mathrm{C}$ and $\mathrm{C}=\mathrm{N}$ stretching modes at about 1585 and $1505 \mathrm{~cm}^{-1}$, respectively, are moved to 1571 and $1500 \mathrm{~cm}^{-1}$.

The UV-Vis absorption spectra of complexes in mixed solution (ethanol and water) is shown in Fig. 1a-b. The spectra exhibit characteristic $\pi \rightarrow \pi^{*}$ and $n \rightarrow \pi^{*}$ (phenanthrolin and terpyridine) in the 263 and $309 \mathrm{~nm}$. As observed in the fig, the peak at 570 $\mathrm{nm}$ is attributed to the charge transfer of $\mathrm{Cr}^{22-24}$.

Cyclic voltammetry was done in an DMF with 0.1M TBAH as a supporting electrolyte at scan rate $100 \mathrm{mV} \mathrm{s}^{-1}$ (Fig. 2a-c). In this voltammogram, two reversible oxidation-reduction and two irreversible reduction couples peaks at -1.2 to $-1.6 \mathrm{~V}$ are assigned to the 4-Ptpy ligand ${ }^{25-26}$. The peaks of -1.6 to -0.9 could be assigned to phendion ligand and $\mathrm{Cr}$ metal ${ }^{27-28}$. The region between 0 and -1 might be related to phendion and 4-Ptpy ligands. In this voltammogram, two quasi-reversible reduction couples at 0 and $-1 \mathrm{~V}$ are assigned to the reduction of to phendion and 4-Ptpy ligands. In comparison with free ligands, the reduction couples shift to more positive potentials due to the coordination of ligands to the $\mathrm{Cd}$ center (Fig. 2c). Also, the figure showed no d-d electron transition for the Cd metal.
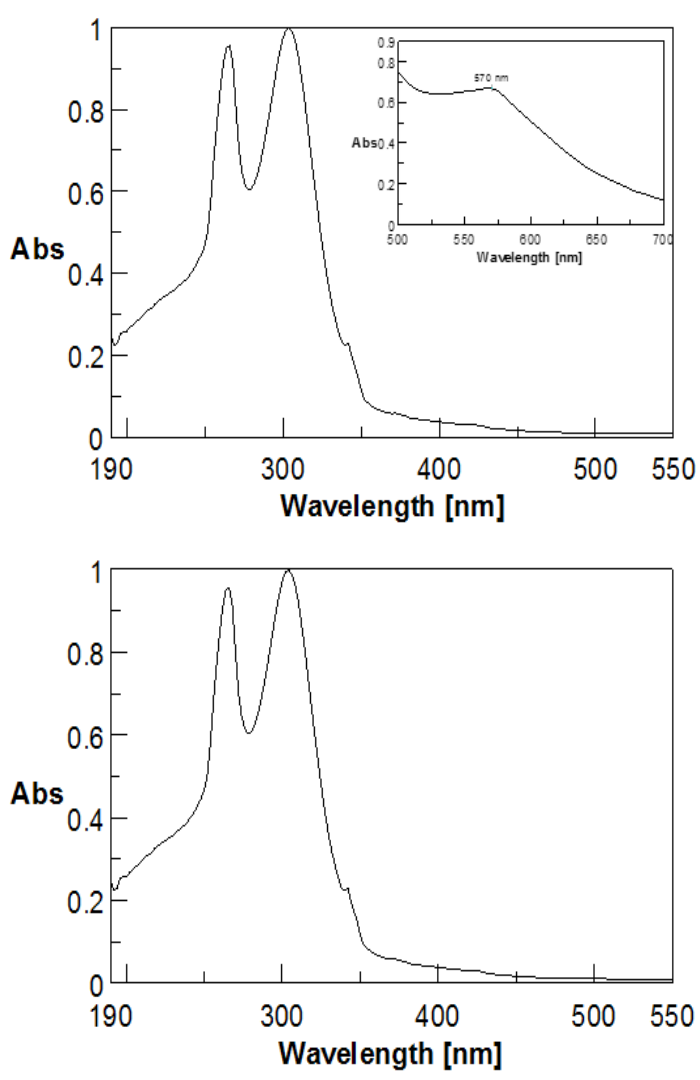

(a)

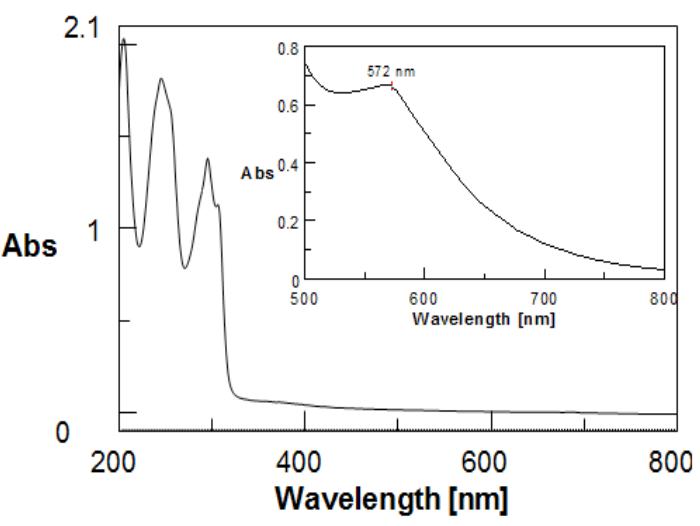

(b)

Fig. 1a, b. The UV-vis spectra of the [(4-Ptpy) Cd( $\left(\mathrm{NO}_{3}\right)$ ( $\mu$-phen-dion) $\mathrm{Cr}\left(\mathrm{NO}_{3}\right)$ (4-Ptpy)] $\left(\mathrm{NO}_{3}\right)_{3}$ 


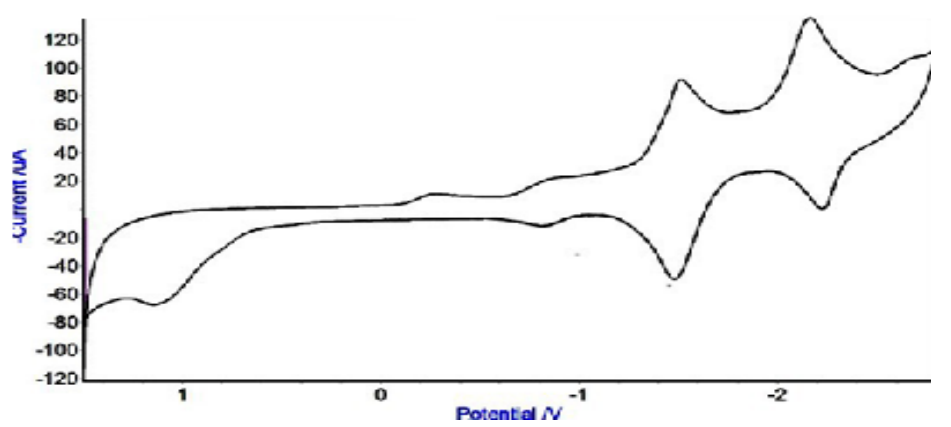

(a)

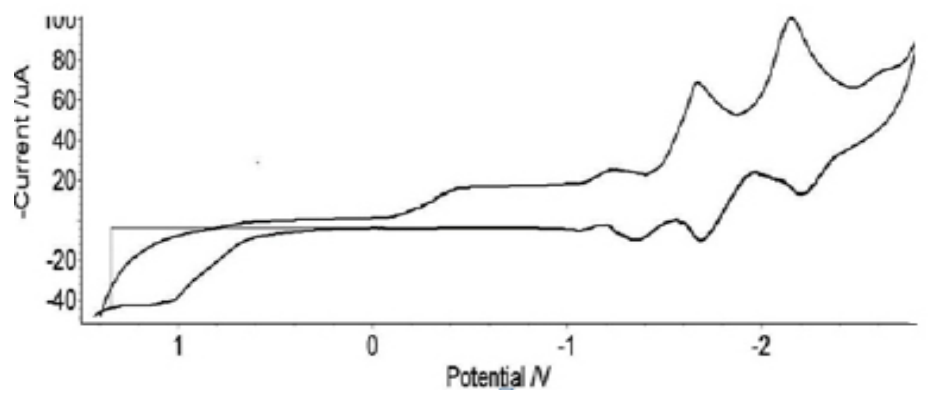

(b)

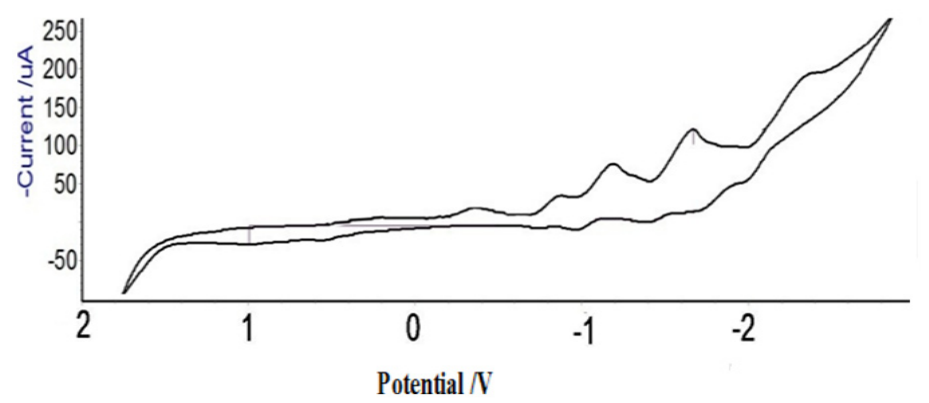

(c)

Fig. 2a, b, c The cyclic voltammetry of the $\left[(4-\mathrm{Ptpy}) \mathrm{Cd}\left(\mathrm{NO}_{3}\right)\right.$ ( $\mu$-phen-dion) $\left.\mathrm{Cr}\left(\mathrm{NO}_{3}\right)(4-\mathrm{Ptpy})\right]\left(\mathrm{NO}_{3}\right)_{3}$

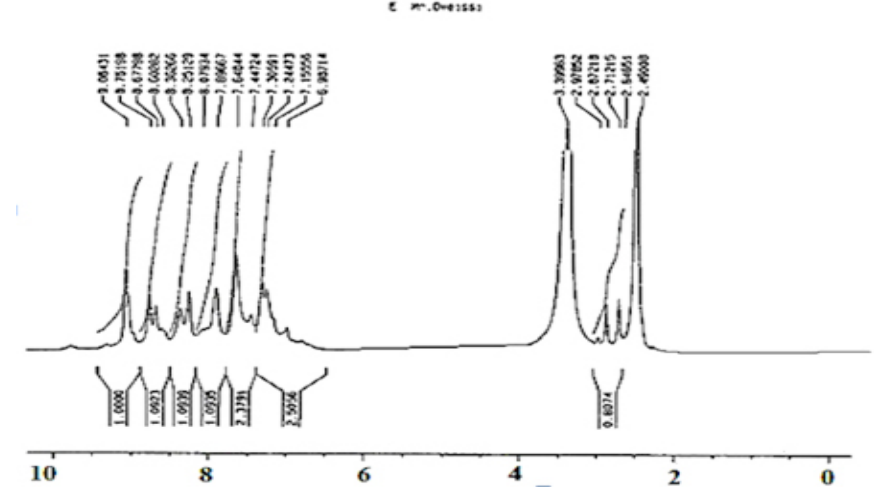

Fig. 3. The ${ }^{1} \mathrm{H}$ NMR spectra of the $\left[(4-\mathrm{Ptpy}) \mathrm{Cd}\left(\mathrm{NO}_{3}\right)\left(\mu\right.\right.$-phen-dion) $\left.\mathrm{Cr}\left(\mathrm{NO}_{3}\right)(4-\mathrm{Ptpy})\right]\left(\mathrm{NO}_{3}\right)_{3}$ 
The ${ }^{1} \mathrm{H}$ NMR spectra of complexes were obtained in DMSO- $\mathrm{d}_{6}$ as shown in Fig. 3. The peaks at 7-9 ppm were assigned to the aromatic compounds $^{29-30}$. The hydrogens of the ligands were observed as doublet and triplet peaks. The peaks of spectra were broad, due to the paramagnetic characteristic of chromium metal ${ }^{31-32}$ (Figure 3).

Elemental analyses of the complexes were obtained, The values confirmed the successful syntheses of the bi-nuclear complexes.

\section{CONCLUSION}

Binuclear $\mathrm{Cr}(\mathrm{III})$ and $\mathrm{Cd}(\mathrm{II})$ complexes containing 4-phenylterpy and phenathroline ligands were synthesized conveniently and characterized by the various techniques. The complexes can further study and apply as semiconductors.

\section{ACKNOWLEDGEMENT}

The authors are grateful to the University of Sistan and Baluchestan for financial support of this work.

\section{REFERENCES}

1. Constable, E.C., Neuburger, M., Diane, R.S., and Zehnder, M., Inorg. Chim. Acta., 1998, 275, 359-361.

2. Laine, P.A., Gourdon, J., and Launay, P., Inorg. Chem., 1995, 34, 5150-5155.

3. Jain, S.L., Alexandra, M.Z., Slawin, J., Woollins, D., and Bhattacharyya, P., Eur. J. Inorg. Chem., 2005, 721-726.

4. Kim, D. S. H. L., Ashendel, C. L., Zhou, Q., Change,C. T., Lee,E, S., and Change, C., Bioorg. Med. Chem., 1998, 8, 2695-2698.

5. Panagiotis, D., Vellis, J.A., Mikroyannidis, LO C.N., and HSU, C. S., Polym. Chem., 2008, 46, 7702-7712.

6. Lebon, E., Dixon, I.M., Vendier., Igau, A., and Sutra,P., Inorg. Chim. Acta., 2007, 360, 1235-1239.

7. Connick, W. B., DiBilio, A. J., Hill, M. G., Winkler, J, R., and Gray, H. B., Inorganic. Chim. Acta., 1995, 240, 169-173.

8. Sawant,V.A. S.N., Gotpagar, B.A., Yamgar, S.K., Sawant, R.D., Kankariya, S.S., and Chavan, s s., Spectrochim. Acta., A, 2009, 72, 663-669.

9. Brandt, W. W., Dwyer, F. P., and Gyarfas, E. C., Chem. Rev., 1954, 54, 959-1017.

10. Hosseini, A, M. W., Kaes, C., and Katz, A., Chem. Rev., 2000, 100(10), 3553-3590.

11. Sugihara, H., and Kazuhisa, H., Coord. Chem. Rev., 1996, 148, 285-299.

12. Bernhard, S., Takada, K., Jenkins, D., and Hector, D. A., Inorg. Chem., 2002, 41,765-772.

13. Brady, J.E., Humiston, G.E., and Heikkinen, H., General Chemistry: Principles and Structure., 1983, 3, 671.

14. Morgan, S. G., and Burstall, F. H.., J. Chem. Soc.,1937, 14, 1649-1655.

15. Ana, C.G., Reinaldo, Z., Oscar, E., Piro, b., and Beatriz, S., and Parajon, Costa., Polyhedron., 2008, 27, 502-512.

16. Xu, W. C., Zhou,Q., Ashendel,C, L., Chang
C. T.,and Chang C. J., Bioorg. Med.Chem., 1999, 9, 2279-2282.

17. Tang, S., Nanotech., 2007, 18, 9-11.

18. Constable, E. C., Housecroft,C. E., Kulke, T., Lazzarini, C., Schofield, E. R.., and Zimmerman, Y. J., Chem. Soc. Dalton Trans., 2001, 2864-2871.

19. Heller, M., and Schubert,U. S., Macromol. Rapid Commun., 2002, 23, 411-415.

20. Constable, E, C., Zhang,G., Housecroft, C. E., and Neuburger, M., Inorg. Chem. Commun., 2010, 13, 878-881.

21. Bernhard, S., Kazutake, T., Jenkins,D., and Abruna, H.D., Inorg. Chem., 2002, 41, 765-772.

22. Constable, E.C., Adv. Inorg. Chem. Radiochem. 1986, 30, 69- 121.

23. Bilica, H.R., and Adkins, H., Organic Synthesis Collective.,1955, 3, 176.

24. Winter, A., Friebe, C., Chiper, M., Hager, M., and Schubert, U,S., Polym. Chem., 2009, 47, 4083-4098.

25. Chao,L., Fan,W., Daniel A. S., Lei,B., Asano,s., Zhang, D., Jie Han., Meyyappan, M., and Zhou,C. J., Am. Chem. Soc., 2004, 126, 7750-7751.

26. Blau, F., and Ber, D., Chem. Ges., 1888, 27, 1077 - 1078.

27. Siddiqi,Z., Khalid, M., Sarvendra, K., Shahid, M., Shabana, N., Eur. J. Med. Chem., 2010, 45, 264-269.

28. Huheey, J, E., Keiter, E.A., and Keiter R.L., Inorganic chemistry principles of structure and reactivity Fourth edition., 1993, 70, 279.

29. Oyama, D., Fujita, R., and Yui,S., Inorg. Chem. Commun., 2008, 11, 310-313.

30. Storrier, G, D., and Stephen B. C., Inorg. Chimica Acta., 1999, 284, 76-84.

31. Brandt, W. W., Dwyer, F. P., and Gyarfas. E. C., Chem. Rev., 1954, 54, 959-1017.

32. Shunmugam.R., Gabriel, G. J., Aamer, K.A., and Tew, G. N., Macromol. Rapid Commun., 2010, 31, 784-793. 